Abstracta Iranica Abstracta Iranica

Revue bibliographique pour le domaine irano-aryen

Volume 28 | 2007

Comptes rendus des publications de 2005

\title{
«L'importanza del manoscritto T III S 16 per la storia della letteratura cotanese ». Litterae caelestes 1, 2005, pp. 159-163.
}

\section{Rédaction}

\section{(2) OpenEdition}

1 Journals

\section{Édition électronique}

URL : http://journals.openedition.org/abstractairanica/10202

DOI : 10.4000/abstractairanica.10202

ISSN : 1961-960X

Éditeur :

CNRS (UMR 7528 Mondes iraniens et indiens), Éditions de l'IFRI

\section{Édition imprimée}

Date de publication : 15 mai 2007

ISSN : 0240-8910

Référence électronique

Rédaction, « «L'importanza del manoscritto T III S 16 per la storia della letteratura cotanese ». Litterae caelestes 1, 2005, pp. 159-163. », Abstracta Iranica [En ligne], Volume 28 | 2007, document 23, mis en ligne le 18 septembre 2007, consulté le 25 septembre 2020. URL : http://journals.openedition.org/ abstractairanica/10202 ; DOI : https://doi.org/10.4000/abstractairanica.10202

Ce document a été généré automatiquement le 25 septembre 2020.

Tous droits réservés 
«L'importanza del manoscritto T III S 16 per la storia della letteratura cotanese $»$. Litterae caelestes 1, 2005, pp. 159-163.

Rédaction

Résumé italien de M., « The manuscript T III S 16 ... ». Voir Abs. Ir. 27, c.r. nº16.

INDEX

Thèmes : 2.1. Langues anciennes

\section{AUTEURS}

\section{RÉDACTION}

Directeur de la revue et secrétariats (Paris et Téhéran) 